\title{
8 \\ Outdoor Play in Wartime Japan
}

\author{
L. Halliday Piel
}

Rarely does the Second World War evoke a mental picture of children at play; instead what grabs our attention is their suffering and sacrifice. In Japan, war meant hunger (and inadequate food rationing), the fire-bombings of major cities by the Americans, child labor for the war effort, child soldiers in the form of volunteer brigades, evacuation of school children from cities into camps, and homeless orphans begging in train stations, not to mention Japanese children abandoned in China during Japan's retreat. In face of the overwhelming narrative of suffering, a discussion of childhood play may seem frivolous and disrespectful.

However, not all children were in the line of fire, and many found moments for play. The interview subjects contacted for this paper invariably apologized for not being among those who suffered, and initially doubted whether their memories of daily life, including play, had much value for an oral history project concerning the war years. ${ }^{1}$ But wartime play matters to historians, partly because wartime leaders sought to indoctrinate the masses in ultra-nationalism through formal education, as well as through informal channels, such as toys, games, and picture-story shows (kamishibai). As it is not possible to observe children in the past, this paper turns to indirect evidence, namely, adult memories of their own childhoods, corroborated by their childhood drawings, when such documents have survived (which is rare). The sample size (nineteen persons) is too small to be treated as statistically significant; rather, the testimony is suggestive of a collective attitude towards child play, supported by depictions of play in wartime children's magazines, a 1943 survey of children's play, and ethnologist Yanagita Kunio's 1941 essay, The Regional Customs of Children (Kodomo füdoki).

How is it that interviewees have happy memories of self-directed, unsupervised play, when the wartime cultural atmosphere in which they grew up expected 
them to shoulder responsibilities alongside their elders? Textbooks and propaganda tracts issued by the Ministry of Education recast children as productive "little nationals" (shōkokumin), while their parents, the imperial national subjects (kōkokumin) or citizens (shimin), were "children" of the emperor father figure. In the words of Norma Field, "the notion of the state as family with all the people as the children" symbolizes "an obliteration of childhood through its universalization" (Field 1995: 66).

Nevertheless, the nineteen interviewees (ten male, nine female), widely dispersed from Hokkaidō to Kyūshū, consistently remember playing "freely" without adult supervision, sometimes alone but more often in groups, even outdoors in the streets or in the backwoods, places that today would be considered dangerous for unaccompanied children (but not for those in Edo Japan; see chapter 2). They report more free time and less homework than their grandchildren, and consider it normal for parents and teachers to stay out of children's games. They insist that this was not parental neglect. They were middle class, the children of small business owners or land-owning farmers; although three identify themselves as elites. ${ }^{2}$ Follow-up interviews were conducted with the most articulate informants.

Was there a cultural space in the wartime mentality that recognized self-directed play as a legitimate part of the "little national" persona? Or was it merely a question of children in the rural hinterland being less affected by the war than urban children? I argue that it was a combination of both: Certain forms of self-directed child play were acceptable so long as they supported what is sometimes called "conservative culturalism" (de Bary et al. 2006: 535) underlying Japanese ultranationalism. At the same time, Japanese children were not all equally affected by the war.

\section{THE PERIODIZATION}

The Second Sino-Japanese War, or Fifteen Years War, is usually defined by historians as beginning with Japan's invasion of Manchuria in 1931. This paper concerns play towards the end of Japan's fifteen-year war, rather than at the beginning. This is because civilian life, including childhood, was reshaped by "total war" policies implemented in the years 1937-41, a watershed moment in the middle of the war. The preceding years are perhaps better understood as an interwar period leading up to Japan's formal declaration of war against Chiang Kai-shek's Republic of China in 1937. In this period, the military gained political power in the Japanese government, and there was a surge of militarism and support for imperialism in popular culture. ${ }^{3}$

The second stage of the war was marked by a full-scale Japanese invasion of China from July 1937 onwards. On the Japanese home front, Prime Minister Konoe implemented total war policies through his National Mobilization Act and National Spiritual Mobilization Campaign in order to better control the civilian economy for the war effort and to drum up support for the war using what Gregory Kasza (1995) has called "administered mass organizations." Life for school-aged 
children changed. They were sent to work on farms during school vacations as part of their "patriotic work service." The type, amount, and duration of work increased as the war went on.

Children were also affected by the rationing system, which became more severe as resources were depleted by a protracted war in China and the opening of a second front in the Pacific after the Japanese attack on Pearl Harbor on 7 December 1941. According to interviews, war shortages reduced access to commercial toys and games, so even middle-class children had to make do with hand-me-down toys from older siblings or to craft their own.

This change is apparent when we take the age of the interviewees into account. Nakajima Shigeru (b. 1932), the son of a small-town business owner in Ibaraki prefecture, spent his allowance on penny candies and cheap cards, available in the dagashiya, a type of sundries store originating in the Meiji period that was popular with children. ${ }^{4}$ The son of a schoolteacher in rural Aomori prefecture, Kubota Haruyoshi (b. 1925) traded store-bought sweets for fruits and nuts gathered in the mountains by impoverished farmers' sons. ${ }^{5}$ But ten years later, a temple priest's daughter in Shiga prefecture, Shingū Mitsue (the youngest of the cohort, born 1937), points out that when she entered elementary school there were no toys or sweets for sale (sugar being severely rationed). As the sixth of eight children, she inherited her sibling's toys and books. She often felt hungry, and her outdoor play partly consisted of foraging for chestnuts or freshwater clams. ${ }^{6}$

Ikeda Giichi (b. 1936), son of a postmaster in a mining town in Kyūshū, made candles out of old wax droppings, and kites and birdcages out of bamboo slivers, which he then sold or bartered. Ikeda showed initiative at a time when consumer goods were scarce and the military commandeered household items made of metal, along with temple bells. Finances were tight in his family of eleven, so Ikeda's play was productive. 7 This comparison illustrates why it is necessary to differentiate between wartime childhood as experienced before and after 1940.

Because economic hardship continued into the American Occupation period, wartime play patterns persisted into the early postwar period, as observed by Peter Grilli, a son of the American Occupation, who grew up in Tokyo from age five in 1947. "Everything we had to make ourselves, or someone else made them in front of our eyes," he recalls of his own play with neighborhood Japanese children in the streets. ${ }^{8}$ Similar observations by anthropologists in the 1950s, such as Beardsley, Hall, and Ward's Village Japan (1959), are still relevant to play in the 1940 .

\section{THE WARTIME CHILD AS PRODUCTIVE “LITTLE NATIONAL"}

In February 1941, the journal Education announced that the Japanese Diet's special task force on education had launched a planning committee, the future Japan Children's Culture Association (Nihon Jidō Bunka Kyōkai), in December 1940 to 
"take absolute lead in creating a new child culture," a euphemism for censoring children's literature ("Jidō bunka no shin-taisei" 1941: 13, 15). Serving on the committee was child psychologist Hatano Kanji (1905-2001). Four months earlier, Hatano had argued in the same journal that "child's mind-ism" (dōshin shugi) was mere infantilization and impeded children's maturation. ${ }^{9}$ He warned that, "This view of the child is based on individualism and liberalism, and does not match reality. So we cannot support it" (Hatano 1940: 245). Hatano advocated the term already in use, shōkokumin or "little nationals." In March 1941, the Japan Children's Culture Association renamed itself the Japan Little Nationals Culture Association (Nihon Shōkokumin Bunka Kyōkai). The term shōkokumin, instead of jidō or kodomo (child), enabled policymakers to envisage child labor for the war effort.

Hatano believed that it was developmentally natural for children to want "to be included in the productive life of adults." He concluded, "Children do not know the hardships involved, so although we should guide them properly, there is no reason for us to suppress their desire to be included." The little national would undergo "training" (rensei) in the newly reformed and renamed "national school." "It means training children for good development, not leaving them freely as they are," Hatano explained. "Training does not mean sharp-tongued scolding. Rather it is about helping them build character and be independent. The childlike child mindset is unable to do this. By spoiling and mollycoddling children, it cannot build character" (Hatano 1940: 246, 247, 249).

Under the National School Ordinance (Kokumin gakkō rei), school children would participate alongside adult mass organizations in prayers at imperial shrines and sendoffs for soldiers. They would perform public service tasks, such as writing letters to the front and working on farms. The schools were to train children and youth to "uphold society, and promote the cult of the emperor, service to the nation, community assistance, respect for rules and the work ethic" (Nihon Seishōnen Kyōiku Kenkyūsho 1983, afterword: 3). "I would like to see a culture that makes children positively participate and work, not one that treats children as precious," Hatano declared. Consumer products for children are extravagant and wasteful, he thought. Instead, children's recreation should be based on production, not on consumption, and on "a children's culture that is truly Japanese" (Hatano 1940: 243). In Hatano's language, there seems to be no room for free and idle childish play. The emphasis is on work for the nation.

\section{PLAY ACCORDING TO INTERVIEWS AND MAGAZINES}

With the increased emphasis on children's responsibilities for the war effort, we would expect less child play in the media, which was now highly censored. Nevertheless, the "little national" image did not preclude play, even while magazines published more images of children doing patriotic work service from 1938 onwards. After all, child's play, like school education, could be employed to disseminate 
propaganda messages to children and adults. Sabine Frühstück argues that militaristic propaganda used the trope of the "innocent child," in the form of children playing soldier or interacting with soldiers, to humanize the war (see chapter 9). Toy makers produced military-themed toys. Children's literature and picture-story shows were coopted to shape children's understanding of Japan's imperial war. In the words of Barak Kushner, "a less easily quantifiable arena of propaganda was after school, on the playground, or on the streets" (Kushner 2009: 245).

A detailed comparison of pre- and post-1937 children's magazine images is not possible here, so I draw on Yamanaka Hisashi's selection of children's magazine illustrations in his Illustrated Children in the War (1989) to represent the wartime ideals of appropriate child play for the little national. There are similarities and differences between the illustrations and the interviews. For instance, pictures show children playing with war-themed board games and commercial toys. Some interview subjects recall sugoroku, the snakes-and-ladders type board game typically associated with New Years festivities. Most, however, recall playing with toys that were either very cheap or made at home. Girls sewed and juggled beanbags called o-tedama (also known as o-jammi). Boys mostly played with cheap cards called menko (also known as patchi or bida, or marui menko in the case of round cards). Players would take turns throwing down a card to flip over an opponent's card with air pressure. A player could claim an opponent's card if it flipped over. The four interviewees who were sons of farmers in Ibaraki prefecture report that they had no commercial toys other than flip cards. Eizawa Kōtarō (b. 1935) made his own stilts (takeuma, or "bamboo horse") and swings. Itakura Nobuo (b. 1931) said that, like all the boys in his village, he made stilts and a flying toy, taketombo ("bamboo dragonfly"). ${ }^{10}$ Nakajima made spinning tops. Shingū folded origami dolls.

In the interviews he has conducted to date, Peter Cave has likewise noticed that beanbags and flip cards are by far the most commonly mentioned games. He surmises that most children "were making their own entertainment," because families before 1945 spent on average about half of their expenditure on food, and only 7-8 percent on "education, recreation, and miscellaneous," according to government data. ${ }^{11}$ On the other hand, schools supplied materials to make toy warplanes. Ueda Hiroaki (b. 1933), the son of a high-ranking Army general, says that his woodworking textbook included patterns for gliders, and that he entered a children's contest for propeller planes. "All boys during the war were airplane maniacs to a greater or lesser degree, absorbed in model making," he recalls later in his childhood memoir, based on his personal diary, which he kept from March 1944, when he was ten, until August 1945 (Ueda 2003: 69-72).

Magazine images represent outdoor play in gendered terms. It is girls who play house on the street in an illustration by Kurosaki Yoshisuke in The Good Child's Play (Yoi ko no asobi), published by Kodansha in 1941. The scene is identifiable as a wartime image by the monpe trousers imposed on women during the war. In a 1938 Kinder Book (Kindā bukku) picture, girls watch from a distance as boys play 
soldier with toy sabers, helmets, and flags. Interview subjects agree that play was segregated at school. Eizawa claims that gender segregation started after the second grade. Male interviewees in this sample recalled playing with male friends, and did not mention playing with girls. When asked, Ueda replies that he never played with girls. Gender segregation, he insists, arises from intrinsic differences: "We male brats quickly form groups, organize ranks, bully or get bullied, swagger and boast, flatter and kiss ass, and try to figure out how to get away with breaking rules." ${ }^{12}$

Female interviewees on the other hand sometimes recall a male playmate. Before she was evacuated with her school, an Army doctor's daughter, Maeda Tokuko (b. 1934), played at home after school with her older brother and his model airplanes. Shingū Mitsue's recollections of outdoor play indicate that boys' groups and girls' groups played in proximity, and occasionally interacted. Shōji Kakuko (b. 1935) in Hokkaidō and Yamagishi Sachiko (b. 1934) in Toyono, Nagano prefecture, state that they regularly enjoyed rough-and-tumble play with boys. Shōjis school diary shows a picture of a snowball fight with boys on the roof of her house. ${ }^{13}$ Yamagishi says that she climbed trees and played soldier with neighborhood boys. (Climbing trees was considered a boy's activity, according to Maeda Tokuko, who avoided it). Nakai Kiyotoshi (b. 1932) describes his childhood friend Yamagishi as a tomboy and leader. He jokes that Yamagishi should have been the boy, and he the girl, because he was shy, preferring to stay at home and study. ${ }^{14}$

The above examples suggest that children's play was mostly gendered according to the norms shown in children's magazines, but that gender segregation was not as strict as magazine illustrations might lead us to believe. Play outside of school appears to have been largely free of adult supervision, which means that there was leeway for gender mixing. There may have been unwritten rules among children for how boys and girls were to interact when playing together. For example, according to Village Japan, in early postwar Japan, "Most boys would not be caught dead playing the games that are popular among girls," but some girls could cross the border into boys' games, such as flip cards (Beardsley, Hall, and Ward 1959: 310).

The shrine festival and the schoolyard were common places for children to play, and appear in illustrations in Children's Asahi (Kodomo asahi), published by the Asahi newspaper in 1940. This is no doubt because city alleyways were too narrow for games requiring space, such as hide-and-seek and tag games such as oni gokko ("play demon"), while country fields might be flooded for rice paddies. Yamagishi's play territory, for instance, was the local shrine (of which her father, a farmer and carpenter, was an important patron). But some children ranged far and wide. They climbed hills to forage for food in the shared village woodland, as in the case of Shōji, who was living in Hokkaidō. In her third-grade school diary, written when she was living in the town of Hakodate, Shōji relates taking a train with friends to the outskirts of town to gather lily of the valley, or play hide-and-seek around the moat of an old fortress. They made up new games, such as biting down on the bean pods of azuki plants to make them pop. 
In the fourth grade, after she and her family had moved to Otaru, Shōji roamed the woods with her small team of friends led by a sixth-grade boy. Once, while they were climbing a hill, it began to pour, and the children made a temporary shelter to wait in until the rain stopped. By the time she returned home it was dark, but her mother was not particularly concerned, just glad to see her safe and sound. "We were really as free as that," Shōji recalls. "Our parents didn’t obsess about our safety." Two years later (by which point the war was over), Shōii's mother scolded her for wanting to learn modern dance. It was a "trauma" she never forgot. What stands in remarkable contrast to today's standards is that her mother considered unsupervised outdoor play normal for children, but was alarmed by the "vulgarity" of modern dance.

An illustration in a 1938 Kinder Book shows two girls and a toddler, all dressed in yukata (summer-weight kimono), sitting on the veranda of a bucolic farmhouse, stringing beads of pearly white seeds called Job's tears (jezudama), which were also used in Buddhist rosaries or brewed as tea. In the background, an older boy is helping a younger girl pick the seeds on a riverbank. Maeda Tokuko says that she was aware that girls made beads from jezudama, which grew in her parents' backyard, but that nobody taught her how to do it. ${ }^{15}$ This kind of rural tradition interested Yanagita Kunio (1875-1962), "Japan's most influential folk scholar" both during and after the war, according to Melek Ortobasi (Ortobasi 2014: 2).

Yanagita collected descriptions of children's games related to Shinto festivals or natural objects that were formerly sacred. For instance, in his 1941 Regional Customs of Children (Kodomo füdoki), originally published serially in the Asahi newspaper from April to May 1941, he writes, “There are many people today who know hook pulling (kagihiki) as a children's game." However, what most do not know is that "from the northern part of Mie prefecture to the Kōga area of Shiga prefecture there is a ritual called kagihiki to welcome the mountain gods into the village in early spring." He believes that the two were related, because both shared the same name and involved pulling hooks. In another homologous game, which Shōji says she played using violets and plantain weeds, a pair of children would pull at two interlocking plant stems. The child whose stem broke would lose. "I do not think that kagihiki and stem pulling, although they are separate games, have separate origins," Yanagita writes. The origin is the hook used in the spring ritual, symbolizing the "hooked branch" that was used as a plow "in the days before iron." Yanagita believes that "people of old recognized from experience the power of the tree branch." "Children's games," Yanagita concludes, "reveal traces of serious rituals from an ancient time when adults were more childlike" (Yanagita 1941: 29-30).

Yet, interview subjects rarely mentioned such indigenous games. Aside from beanbags and flip cards, they describe games they played with their school groups. Some of these games point to cross-cultural diffusion during Japan's modernization in the Meiji period. Ueda drew a picture of playing "kick horse" (uma keri, see figure 9), in the school gym. He no longer remembers whether it was part of 


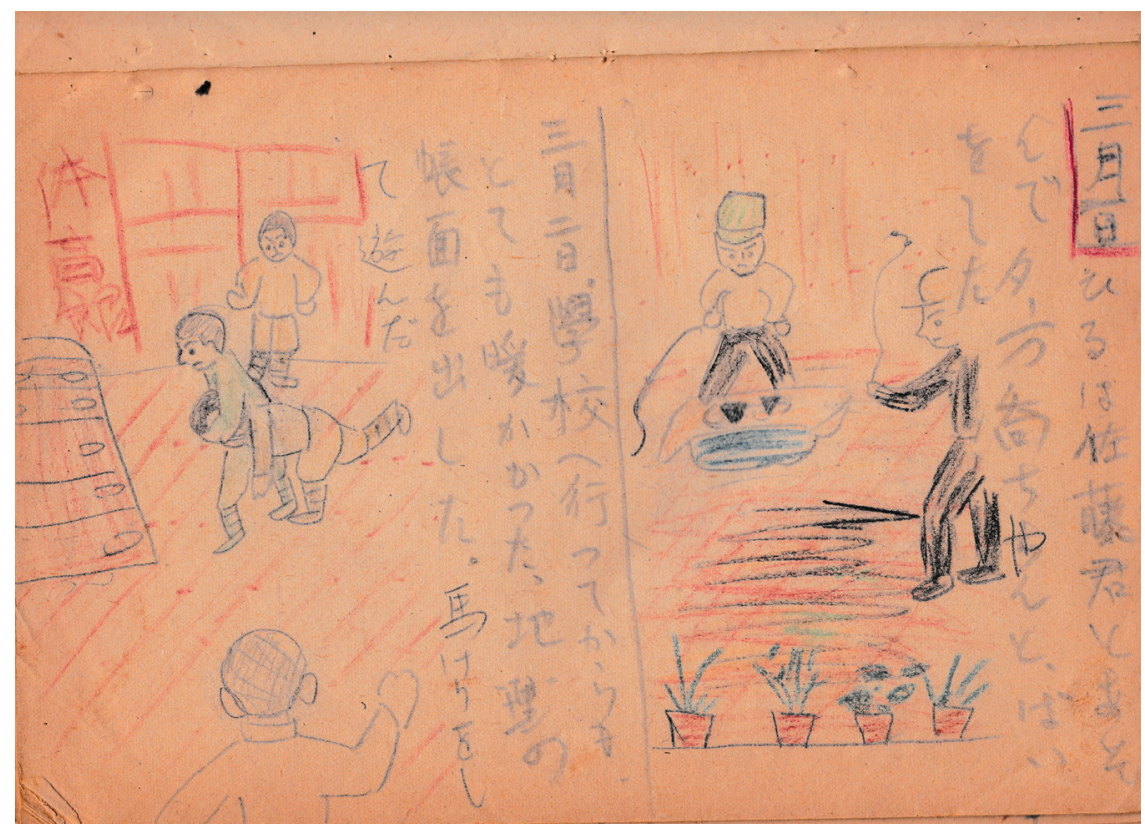

FIGURE 9. Uma keri (kick horse), drawing by Ueda Hiroaki, 1945. Courtesy of Ueda Hiroaki.

physical education, but the game is possibly a variation of uma tobi ("jump horse"), played by Kinoshita Masako (b. 1933) in Osaka. Both games involve one or more children forming a "horse." In the case of "kick horse," the "horse" tries to rearkick an opponent. In "jump horse," the opponents hop onto the "horse" one after another until it caves under their weight. Yanagita sees a tenuous link between "jump horse" and "Deer, deer, how many horns?" (Shika, shika, nannpon), in itself a variation of "How many horns has the buck?" once played widely in Europe. An elderly woman in Niigata prefecture told Yanagita that she remembered learning "deer deer" from an American teacher at her girls' school in the early Meiji period (Yanagita 1941: 88). Thus it is possible that a foreign game initially introduced by Western educators evolved over time into a version transmitted by Japanese teachers at school (perhaps "kick horse") and a variant played by boys in the street ("jump horse").

Can kicking (kan keri), recalled by Maeda, is clearly the game known as tin can tommy in England and by various names, including kick the can in the United States, which "seems to have been well known in city streets before the First World War," according to Iona and Peter Opie. It elaborates the basic hide-and-seek pattern, with a can to mark territory where the seeker will hold captive hiders until they are rescued by fellow hiders (Opie and Opie 1969: 165, 167). Variations on this 
theme include play battleship (senkan), a war game described to me by Ueda, in which a minelayer must "sink" either one battleship or several destroyers. The orientation of the visors on the boys' caps indicates which type of ship they are playing.

Maeda played drop the handkerchief (hankachi otoshi), an "old and muchloved game in England" since the eighteenth century (Opie and Opie 1969: 168). To stay warm in winter, she played oshikura manjū, in which children cluster with their backs together, trying to shove each other out of a ring. ${ }^{16}$ This is suggestive of sumo wrestling, a version of which (oshidashi or "frontal push out") Maeda did in her physical education class.

\section{THREE CONCEPTS OF PLAY ACCEPTABLE FOR}

\section{"LITTLE NATIONALS"}

The preceding narrative indicates that wartime children were still playing games known before the war, unaware that some of them had Western roots. Adults seem to have tolerated games played in the street, while actively encouraging some at school. Wartime educators clearly saw value in the latter. Here I propose three reasons why prewar games might retain relevance to a cultural climate of censorship that was unfriendly to consumerism, individualism, frivolity, idleness, and Westernization. By no means does this scheme constitute a complete picture of play as variously theorized by educators, psychologists, and anthropologists, or even as a complete picture of play during war.

The first reason is that play can be a form of learning adult roles, even if it involves some fantasy or make-believe. Ueda was still "playing" when he made model airplanes in 1944, but in that same year, many middle-school students were mobilized to aircraft and munitions companies where they made airplane parts for real. Thus, Ueda's play can be seen as preparing him for a possible role in the war. The line between "play" and "work" is blurred. Although it is appropriate play for the little nationals, it carries some risk when it is self-directed. For instance, in a private diary entry of 5 June 1944, the eleven-year-old Ueda praises the enemy planes: "The B-29 has a really good shape," and the P-51 Mustang "is the world's coolest airplane." Such statements would have been unacceptable in the classroom.

A second reason is that play can transmit state-sanctioned culture. In the conservative cultural climate of the war there was value in games handed down through the ages, such as those associated with festivals and holidays reinforcing community traditions. Because conflict between nations intensifies national consciousness, any game seen to reflect Japanese identity would be appropriate for the little nationals. Yet, when self-directed, traditions can be distorted or mocked by using taboo words as well as scatological or sexual jokes, at which point, play may become, in the words of anthropologist Allison James, "as much about social disorder as order" (Montgomery 2006: 145, 147). 
No such cases have been brought to my attention, but Ueda has heard of wartime schools banning top spinning (begoma), flip cards, and marbles (biidama) for their presumed association with "gambling." ${ }^{17}$ Ironically, top spinning and a game similar to flip cards, flipping chess pieces (jögi taoshi), appear in a woodblock print by Utagawa Hiroshige, depicting boys' games around 1830. The girls' game hajiki, also played like flip cards but with flat marbles, is described in Ōta Sajirō's threevolume compilation of children's games by region (Nihon zenkoku jidō yūgihō), published by Hakubunkan in 1901. Thus, merely being old does not necessarily qualify a game as "traditional" (or ancestral) in the formulation of the wartime Japanese spirit.

A third reason is that play may be seen to have physical or spiritual benefits. Play in nature, which includes hunting, fishing, netting insects, gathering fruits and nuts, as well as chase games requiring space, may contribute to physical strength, health, and nutrition. Interviewees often mentioned climbing trees and swimming in rivers. However, when unsupervised, such play carries the risk of serious injury.

Free outdoor play has been associated with progressive education for imaginative, self-expressive individualism since Jean-Jacques Rousseau penned his Émile, or On Education (1762). In Japan, progressive educators in the interwar era experimented with new concepts like the Seaside School, founded in 1921 in Nagasaki, and the Roofless Kindergarten in Osaka prefecture. The leading kindergarten expert Kurahashi Sōzō prescribed the types of games permissible under the rubric of free play, which, of course, is not the same thing as letting children do as they please. His choice of games would be familiar to wartime children: playing tag, playing house, and playing war, along with stringing paper flowers, and playing "rolling ball" (tama korogashi), a variant of marbles or pinball on a wooden track (Suwa 1992: 146).

Certain child-centered developments of the interwar period may have been as much about adult efforts to control the development of children towards an ideal as they were about giving children more freedom. In Mark Jones's words, educated elites in the Taishō period (1912-1926) envisioned play as "child's work" and "accidental education," and they "folded the child's play world into a search for authentic experience and a solution to the deficiencies of civilization," namely a more humanistic and "cultured living" (bunka seikatsu) (Jones 2010: 251, 262, 263, 288). David Ambaras (2006) sees a less benevolent, more coercive, attempt to socialize "delinquent youth" in the seemingly altruistic efforts to protect juveniles made by government officials, concerned mothers, welfare reformers and religious groups. Such findings suggest that caution is necessary when examining the "progressive" and "child-centered" rhetoric of interwar "Taishō liberalism." There are underlying continuities between one era and the next. What changes between 1921 and 1941 is not so much the type of game, or the extent of children's freedom, but rather the ideal to which adults hoped to shape the child's development.

Why were there not injunctions against free play in Education (Kyōiku, a journal produced by the publisher Iwanami Shoten between April 1933 and March 
1944) during the war comparable to warnings against progressive children's literature? One possibility is that adult authorities did not take play among children as seriously as they took the messages that adults might disseminate to children through education, leisure reading, and consumer products.

Play was not a prominent theme in Ministry of Education documents, unlike children's literature, which had its own wartime committee starting in 1938. However, the Japan Youth Education Research Office sought to make the case for the importance of play in its 1943 survey of six schools (two rural and four urban), conducted the previous year. This research institute was founded in 1941 in conjunction with the formation of the Great Japan Youth Association. It produced two publications about "training youth for social life" before releasing the 1943 study on play. "Social life" (shakai seikatsu) meant the cooperative performance of duties expected of neighborhood associations mobilized for the war effort (Nihon Seishōnen Kyōiku Kenkyūsho 1943, 3-5). The survey on play must therefore be seen in the context of the greater agenda of civilian mobilization for total war.

In the preface, the author explains that child play "on the one hand has meaning as training (shüren), and on the other hand can be seen as a child's form of public affairs (köji)." In the classroom, the author continues, the child's relationship is with the teacher. "So the child's interaction with other children naturally occurs through play. In our eyes it follows that for children, play is actual life and constitutes social life (shakōtekina seikatsu). A child who does not play is cast out of children's society." Here we see that the author respects children's self-organized interactions with peers, free of teacher influence, as a form of training in social intelligence for group cohesiveness. In the context of civilian mobilization, teamwork and team spirit were essential learning outcomes. "If we are to guide play" (presumably towards this ideal), the report states, "we first must understand how children play” (Nihon Seishōnen Kyōiku Kenkyūsho 1943: 88-90).

The survey finds that 53 percent, mostly girls, of 1,385 children play "athletic games" (e.g., tag and hide-and-seek), 10.5 percent do imitative role play (e.g. playing house and playing soldier), while 8.1 percent, mostly boys, forage in nature. The remaining five categories (involving activities such as making things, luckbased games, watching films or listening to records) were "extremely few" (Nihon Seishōnen Kyōiku Kenkyûsho 1943: 90, 93-95). Although there are differences from my interview sample (in which luck-based games-flip cards and beanbags for example-are the most commonly remembered), the report supports the interviews by indicating that outdoor play among peer groups was the norm.

YANAGITA KUNIO: THE VOICE OF FREE PLAY IN THE WARTIME CULTURAL CLIMATE

Yanagita Kunio is not mentioned in the 1943 report, but his discussion of traditional games provides a key to understanding why autonomous peer groups could 
be seen as beneficial to society. His Regional Customs of Children was not about contemporary play. Rather it concerned the memories of grandparents in rural farm communities. "Parents in the olden days almost never thought up games for children," he writes. "And children were not unhappy about it, but grew up playing to their hearts' content. This is a significant difference with the children's culture of today" (Yanagita 1941: 39). Here, Yanagita waxes nostalgic for an imagined loss of autonomy, even though the 1943 report suggests otherwise. This is probably because Yanagita's real interest was not children but Japanese indigenous culture, which he believed could be found in games of the past. He had read the work of British anthropologist Edward Burnett Tylor (1832-1917), who in 1879 proposed tracking cultural evolution through the transmission of children's games (Montgomery 2009: 142). One contributor to Folklore (Minkan denshō), a journal founded by disciples in Yanagita's Thursday Club, writes that the games in Regional Customs demonstrate Hans Naumann's (1886-1951) theory of gesunkenes Kulturgut ("sunken culture," or chinka bunka in Japanese) according to which the primitive rituals of an elite trickle down to ordinary people and become folk culture. The key to tracking this process in children's games is to look for patterns in game vocabulary across regions (Kuchida 2012 [1941]: 146).

Although his methodology drew on Western scholarship, Yanagita differs from his Western counterparts, according to Mori Kōichi, in viewing human culture not as discreet "stages as development" but as the "coexistence" of primitive and modern "spiritual structures" (Mori 1980: 90). In the rituals of folk religion, Yanagita hoped to uncover the still living essence of the Japanese spirit. In that sense, he can be viewed as one of the "Return to Japan" intellectuals who sought to define what it meant to be Japanese in the context of global modernity and competing nationstates. The Kyoto School philosophers of "Japanese spirit" or "Japanism," for example, studied Western thinking to rediscover Japanese identity by comparison. ${ }^{18}$

Yanagita's vision of premodern childhood required children's autonomy and agency in order to transmit the primitive traces of indigenous spiritual life. His chapter on playing house is not about playing house with toy utensils as shown in the children's magazine mentioned earlier. Rather, it harkens back to the living memory of grandparents in rural areas, when village girls gathered on beaches or uncultivated fields together to cook "spirit food" (seirei meshi) during the Obon (All Souls) festival using a small portable stove without the help of their mothers. In some regions, Yanagita explains, younger girls cooked under the supervision of an older one. In others, only girls of "marriageable age" (sixteen or older) prepared the food. Yanagita sees in this cooking ritual a rite of passage, qualifying girls for marriage (Yanagita 1941: 61-62). The custom began dying out in the 1920s (Moriyama and Nakae 2002: 237-38).

Similarly, boys had their own self-governing groups (kodomo gumi, not to be confused with wakamono gumi, associations of young men). Boys' groups dating back to the Edo period (160o-1868) carried portable shrines in Shinto festivals, 
and exorcized ghosts during the New Year's and Obon celebrations. In the Sagichō festival, during the New Year, boys in some regions would gather under the leadership of a fifteen-year-old "czar" (oyadama) or "general" (taishō), and build huts, spending several nights together before torching the huts in an act of exorcism. Yanagita claims that this custom ended around the time of the Manchurian Incident (1931), when a boy sleeping in one of the huts was inadvertently burned to death (Yanagita 1941: 58).

In one Obon custom, boys in outlying villages near Osaka were allowed to steal dumplings specially made for the occasion. They would slide a sharpened stick through a hole in the neighbor's fence in order to lift a dumpling from the strategically placed pile. Some towns sanctioned pranks, such as blocking off roads with mud-coated ropes, badgering passersby for spare change, or intruding in a family's attempt to make dinner. Adults tolerated the pranks because they believed that children (like Shinto priests) represented the gods during Obon season. Yanagita points out that such mischief is no longer tolerated "today" (in 1941).

Shōji remembers making a clay oven for the Obon festival, while Nakajima recalls a "midwinter" game called natto thief (natto dorobō), in which children would "steal" natto (fermented bean paste) from a neighbor's kitchen, not unlike Yanagita's dumpling stealing. However, he also says that New Year's was not as important as it is today. His wife Kimiko, a salesman's daughter in Ibaraki prefecture, likewise says that the doll festival was not the big affair it is today. Shingū remembers that her town's Hachiman and Sagichō festivals were canceled during the war. Most of Shingū's nature-related play involved foraging for food in the hills and swamps of Ōmi Hachiman, either alone or with neighborhood children. Ironically, the war may have temporarily undermined the connection between children's games and ritual festivals that fascinated Yanagita.

In sum, Yanagita's view of play included the concepts of play as learning, play as transmission of culture, and play in nature. He accepted self-directed free play because traditionally it took place in peer groups, socializing children for village life. "His conception of the individual was not that of an autonomous subject guided by his own will," Mori Kōichi explains, "but one whose daily life has its foundation in the group" (Mori 1980: 104). The absence of individualism in Yanagita's vision of play could be construed as compatible with the aforementioned 1943 report, which had been produced in the context of the Ministry of Education's attempt to control children's culture.

Yet, to complicate matters, Yanagita was an intellectual maverick, and his relationship with wartime ideology continues to be debated by historians. In an essay, "About our Ancestors" of April-May 1945, according to Mori, Yanagita "insists that his idea of ancestor worship does not harmonize with that of 'the state as family' (kazoku kokka), the official ideology of the Meiji and Shōwa wartime governments," and thus he "opposed facile universalization" (Mori 1980: 96, 99). For him, the "group" meant the household and the small community, and he favored 
the small tutelary village god over State Shinto. Perhaps for that reason he did not use the word little nationals when referring to children. He criticized the Imperial Rescript on Education for being based on Confucian obligations, preferring to view loyalty to the emperor as an authentically "religious feeling" (Mori 1980: 105, 107).

In Regional Customs, Yanagita indirectly takes aim at the school system, writing that, "compared to the system of separating children by age in elementary school," children in the olden days enjoyed the responsibility of passing on their games to younger ones, while being conscious of growing up. "There was nothing more fun than figuring out by themselves the ways to play, the names of things, the words of songs and the movements" accompanying games" (Yanagita 1941: 39). Here, Yanagita implies that by separating age groups, the school system was interrupting the transmission of folklore, the root of Japan's cultural identity. Ortabasi explains that Yanagita went against the grain of centralized education because he opposed modern language reform in the late Meiji and Taishō periods. A Tokyo dialect had been chosen as a common language to help nationalize the masses. Yanagita wanted the common language to evolve organically from the bottom up, on the basis of local dialects, instead of being imposed from the top down. Only in this way would a national language be the result, not the cause, of Japanese identity (Ortobasi 2014: 17-18).

"Games and children's made-up words, like song and dance, are flip sides of the same coin," Yanagita writes in Regional Customs, before gently taking aim at the games that educators compose for children: "Even in the new games of elementary school, educators try as much as possible to add modern songs (shōka), but maybe because of the way the lyrics are mixed in, children put too much effort into the words and treat the movements lightly, or become so absorbed in the game that they play it silently" (Yanagita 1941: 16). He turns to "bird in a cage" (kagome kagome) to illustrate how children in the past found their own perfect combination of rhythmic words and movements. Chanting children dance in a circle around a seated child, who must guess which dancer stands behind him or her when the dancing abruptly stops. Yanagita takes particular interest in guessing games, but never describes war games, not even sword play (chanbara), which surely has a long history.

Ueda dismisses Yanagita's guessing games as the sort of thing only girls would play. Indeed, it is a woman, Shingū, who recalls a similar game, one monme of flowers (hana ichi monme), in which two opposing groups of girls skip back and forth chanting a song that begins, "Bridal trousseau chest-which child do you want?" (Tansu nagamochi dono ko ga hoshii). ${ }^{19}$ Taking turns, one girl from each side summons a child from the other side to come over, while performing a challenging task, such as hopping on one leg. Shingū recalls a girl bursting into tears when she could not do a somersault on command. Shingū learned this game from her neighborhood peers. Her mother and older sisters were too busy working for 
the war effort to play with her. Her story provides one indication of how the war both impeded and furthered Yanagita's ideal of play by shutting down shrine festivals while weakening the influence of parents.

\section{GEOGRAPHIC AND OTHER CONSTRAINTS}

Although all interview subjects claim that their games were self-directed, it must be acknowledged that the degree of freedom relative to adult intervention varies. No interviewee self-identifies as a child of the working poor (tenant farmers and menial laborers), so the focus here is not on socioeconomic differences, but on whether the child lived at home or was evacuated during the American fire bombings of 1944 and 1945. Evacuation altered the types of play experiences taken as normal in the aforementioned 1943 report.

It is no accident that Shōji, whose play was most "wild and free," was living in Hokkaidō, surrounded by nature and insulated from American bombing raids. Maeda, on the other hand, was evacuated with her elementary school, first to a farm in Kumegawa, a suburb of Tokyo, and then to the town of Fukumitsu in the alpine region of Toyama prefecture. Her school diary before evacuation contains many more pictures of play than after the evacuation, when she began recording communal dormitory life. The school now planned her day from breakfast to bedtime, leaving less time for free play.

A chronology of events compiled in 1989 by twenty members of Maeda's alumni circle from their wartime picture diaries shows that chores increased for the older students. For instance, in Kumegawa in September 1944, fifth-grade pupils cut grass, pulled weeds, and gathered firewood, in addition to the chores they shared with the third and the fourth graders, namely, picking beans and preparing the communal bath. Only the youngest cohort, the third graders, "played with rabbits" (Ochanomizu gakudō sokai no kaihen 1989: 12). The class timetables of fourthgrade girls and sixth-grade boys show that both groups had five hours of classroom education from Monday to Saturday, but that the sixth graders had an additional hour of "work" (sagyō) (Ochanomizu gakudō sokai no kaihen 1989: 38). Maeda, who was in fifth grade, reports that her chores in Kumegawa included peeling potatoes, cutting grass, hauling well water, gathering sticks to use as fuel to heat the bathtub, and washing towels. In Fukumitsu, she transported food and took turns with her classmates taking charge of a bath at the house of the sake brewer who lodged them. At 8 p.m., there was an hour of free time before bed, which she chose to spend writing her diary and postcards home. ${ }^{20}$ Being a member of the elite (as a doctor's daughter), Maeda had grown up with maid service and was unaccustomed to doing chores. So, naturally, before evacuation her afterschool time had been spent on play.

When the evacuees moved to Fukumitsu, the amount of classroom time fell to three to four hours per day, which restored time for play that had been lost 
in Kumegawa. Yet, it was not free. Teachers kept an eye on the schoolyard, and supervised children swimming in summer. They prohibited mixing with local children. Maeda's contact with children outside the group was limited to the son of the sake brewer in whose house she lodged. Obviously this situation reduced the transmission of culture among children. Maeda was surprised to learn later in life that evacuees at a different school ate the roasted beans inside their beanbags. "I didn't have the wisdom to figure that out," she says. "I doubt the sixth graders knew either. If they had, they would have told us how." ${ }^{21}$ Maeda learned to juggle beanbags by watching a teacher demonstrate. Another teacher taught her to knit. However, she learned to play cards by watching the older girls.

Even children who were evacuated individually, not in groups, faced disadvantages in terms of free play. Oota Masami (b. 1936), the son of a salesman in Osaka, was sent to live with his aunt and uncle in a family of nine in Kumihama, outside Kyoto. Oota was left out when his classmates went swimming in the river or foraging in the woods for mushrooms, because he did not know how to do either. ${ }^{22}$ Ueda likewise believes that he was discriminated against as an outsider when he and his mother moved three times to escape the Tokyo firebombings. According to Ueda, veterans of school evacuation mistakenly believe that children evacuated individually had an easier time just because they lived with relatives. But being evacuated individually, instead of together with school companions, placed Ueda and Oota at a disadvantage when it came to playgroups. ${ }^{23}$

Local farm children were in a better position than evacuated children to be "wild and free" in nature, but with the caveat that they could be put to work at a young age. Oota believes that fifth-grade and sixth-grade pupils in Kumihama did not have much time for play because the commute to school took one hour each way on foot, and then there was farm work to do at home for family survival. When Ueda entered the Kamisato school in Toyono, Nagano prefecture, he was put to work on a farm with his sixth-grade class starting in March 1945. As a result, pictures of his agricultural work dominate his personal diary from March onwards. Gone is the variety of games he used to play. Instead, his leisure activities are limited to aiming at sparrows with slingshot, or looking at pictures of airplanes in magazines and playing Japanese chess (shōgi), usually while sick in bed, after getting a fever from the festering of cuts and blisters suffered during farm labor. Maeda escaped farm work, possibly due to her elementary school's high status, being affiliated with the Tokyo Women's Higher Normal School (now Ochanomizu University). However, as explained above, evacuation curtailed free play in other ways.

\section{POSSIBLE DIALOGUE WITH THE POSTWAR "EDUCATION CRISIS"}

Memories of free play notwithstanding, these anecdotes illustrate how the worsening of the war affected play by making demands on children's time and by 
disrupting daily lives, especially in the case of children over ten or those who were evacuated. Still, there is little way to verify the memories of interview subjects. One interviewee has no memories of play during her school evacuation (she was in the same school as Maeda), even through her school diary contains a handful of pictures of play. $^{24}$

Because most interview subjects nevertheless report freedom relative to their grandchildren, it is necessary to consider the possibility that their memories are shaped by an unconscious dialog with contemporary issues, which is a phenomenon observed by scholars in the context of war trauma memory. ${ }^{25}$ Being adults, not children, the interview subjects remember their childhoods through the lens of seeing their own children and grandchildren grow up under different circumstances. Their memories may have also been shaped by the barrage of media concern in the 1980 o about school bullying, school refusal, and "adult diseases," blamed by child experts on the stress of "education as endless labor" (Field 1995: 53). Experts at the time attributed children's bad behavior to a lack of social skills, caused in part because "children were spending less time in experiences of play, daily life, and nature." Such concerns drove the education reforms of the $1990 \mathrm{~s}$ (Cave 2007: 18).

In addition to having less time, children today have less space. As Howard Chudacoff points out in the context of American history, "between the colonial era and today, natural play sites have diminished, thus reducing the ability of children to go 'roving' and 'roaming'" (Chudacoff 2012: 215). Meanwhile, the new virtual play spaces online are poorly understood in terms of their impact on children's development of social skills. Anxieties about change may thus lead interview subjects to privilege in memory what they perceive is missing in contemporary childhood. Another possibility is that remembering "freedom" is overcompensation for the embarrassment of wartime "deindividuation," to borrow a term from social psychology. In Keiko Matsuki's words, “The narrative is not a simple reflection of experience, but ... reconstitutes our identity." In the act of remembering and narrating life experiences, the narrator invests old memories with new meanings to explain how past behavior is still consistent with current self-image. Matsuki theorizes that people born between 1926 and 1934 try to negotiate the 18o-degree flip in their identities caused by Japan's surrender by recalling "rebellious" thoughts towards symbols of pre-defeat authority, such as teachers and policemen (Matsuki 2000: 536, 538). Perhaps free play falls into the category of rebellious memory.

However, a likely explanation in my view is that what may be called a "return to free play" is actually a "transwar" concept, to borrow a term from Andrew Gordon, allowing interview subjects to take comfort in a particular continuity between past and present thinking about childhood. According to anthropologist Joy Hendry, postwar Japanese educators appear to take the idea of socialization through peer groups as self-evident, and even manipulate peer pressure to control children's behavior in the classroom (Montgomery 2006: 129). Yanagita's privileging of 
children's self-directed play over games designed by adults may be echoed in the Ministry of Education's decision in the 1990s to increase school holidays, supposedly so that children would have more free time "to learn freely through experience and exploration outside of school" (Cave 2007: 19). Some games that Yanagita loved and upheld as manifestations of Japanese spirit, such as bird in a cage, continue to be taught in elementary schools and kindergartens by teachers aware of the nation's cultural heritage (Peak 1993: 48, 82).

\section{CONCLUSION}

Japanese children between 1941 and 1945 enjoyed self-organized free play according to interviews, even though the wartime concept of the little national emphasized duty and work ethic, rather than choice and leisure. Despite wartime shortages of consumer toys, there was a rich and varied culture of children's games that children learned at school, or more informally from each other after school in neighborhood green spaces, such as the village shrine or communal woodland. Some of these games were rural traditions, romanticized by Yanagita Kunio as important to Japanese identity.

Using interviews, and magazine illustrations, a wartime survey, and Yanagita's Regional Customs of Children as a barometer for the wartime cultural climate, I conclude that child play was acceptable as a form of learning, physical exercise, and transmission of Japanese identity. Unsupervised play was tolerated because adults like Yanagita believed that autonomous play in groups promoted socialization for harmonious cooperation, not selfish individualism. Rather, it was the interwar-era proponents of the "childlike child" who could be accused of interfering in children's natural play with their foreign educational games and playground equipment.

Yanagita's thought was not identical to nationalistic statism. His suspicion of top-down education and his preference for grassroots initiative enabled his ideas to survive into the democratic postwar era. The notion that free play is both desirable and endangered still resonates strongly with adults today, enabling the wartime generation to remember free play without shame, if not with pride. In practice, however, there may not have been quite as much freedom as remembered. From late 1944, children evacuated in school groups experienced a more regimented lifestyle, organized and monitored by teachers. In that sense, they may have been more like the cram-school generations after the war than like their rural peers, whose lives were not (yet) turned upside down by the war.

\section{NOTES}

1. This research is supported by the project "Remembering and Recording Childhood, Education and Youth in Imperial Japan, 1925-1945," directed by Peter Cave, University of Manchester (UK), funded by the UK Arts and Humanities Research Council. 
2. Interview subjects do not use this term. In postwar Japan, class differences tend to be downplayed, or indicated indirectly through one's place of residence. Here, "middle class" is used according to Andrew Gordon's designation of a "mainstream" (chüryz̄) that emerged between the 1920 and the 1960 s and engaged in consumption and leisure (2007).

3. See, for example, what Louise Young calls the "cultural deluge" of popular media support for Manchukuo, the "puppet state" under construction by the Japanese Kwantung (Guandong) Army (Young 1998: 69).

4. Nakajima Shigeru, interview, Tsukuba, Ibaraki-ken, 8 January 2014.

5. Kubota Haruyoshi, interview, Tokyo, 10 August 2010.

6. Shingū Mitsue, interview, Ōtsu, Shiga-ken, 10 August 2010.

7. Ikeda Giichi, interview, Kumamoto, Kumamoto-ken, 2 January 2014.

8. Peter Grilli, interview, Auburndale, MA (USA), 12 June 2013.

9. This term refers to child-centered romanticism in the progressive children's literature of the previous Taishō era (see chapters 4 and 5).

10. Eizawa Kōtarō, interview, Ishiku, Ibaraki-ken, 7 January 2014.

11. Personal communication, 7 February 2015.

12. Email correspondence, 16 January 2015.

13. Shōji Kakuko, interview, Honolulu (USA), 29 December 2013.

14. Takatsu Yoneko, Yamagishi Sachiko, and Nakai Kiyotoshi interview, Toyono, Nagano-ken, 12 June 2015.

15. Maeda Tokuko, interview, Kawasaki, Kanagawa-ken, 9 June 2015.

16. Maeda Tokuko, interview, Kawasaki, Kanagawa-ken, 15 January 2014.

17. Personal correspondence, 10 February 2015.

18. Takeshi Morisato, "What does it mean for 'Japanese philosophy' to be 'Japanese'? A Kyoto School discussion on the peculiar character of Japanese Thought," presented for the British Association for Japanese Studies Annual Conference 2015, School of Oriental and African Studies, University of London, 11 September 2015.

19. A monme is a unit of coinage used in the Edo period (1600-1868)

20. Email correspondence, 7 January 2015.

21. Maeda, interview, 9 June 2015.

22. Oota Masami, interview, Tokyo, 9 January 2014.

23. Aaron Moore has suggested in personal conversation that school evacuees formed their own cultural identities, not just during the war, but years later through class reunions.

24. Mikawa Sueko, interview, Kawasaki-shi, Kanagawa prefecture, 17 June 2015.

25. For instance, some atomic bomb survivors decided to tell their stories "out of a sense of urgency and with a great deal of self-awareness about the act of telling the past" because they oppose recent government efforts to remilitarize or revive patriotic education (Yoneyama 1999: 86).

\section{BIBLIOGRAPHY}

Note: Unless noted otherwise the place of publication for Japanese books is Tokyo.

Ambaras, David R. 2006. Bad Youth: Juvenile Delinquency and the Politics of Everyday Life in Modern Japan. Berkeley: University of California Press.

Beardsley, Richard K., John H. Hall, and Robert E. Ward. 1959. Village Japan. Chicago: University of Chicago Press.

Cave, Peter. 2007. Primary School in Japan: Self, Individuality, and Learning in Elementary Education. London: Routledge. 
Chudacoff, Howard. 2012. "Play and Childhood in the American Past: An Interview with Howard Chudacoff." American Journal of Play 4 (Spring): 395-406.

de Bary, William Theodore et al., eds. 2006. Sources of Japanese Tradition 1600 to 2000, abridged edition. New York: Columbia University Press.

Field, Norma. 1995. "The Child as Laborer and Consumer: The Disappearance of Childhood in Contemporary Japan." In Children and the Politics of Culture, edited by S. Stephens, 51-79. Princeton, NJ: Princeton University Press.

Gordon, Andrew. 2007. "Consumption, Leisure and the Middle Class in Transwar Japan." Social Science Japan 10(1): 1-21.

Hatano Kanji. (1940) 2012. "Jidō bunka no taisei" [The child culture system]. In Jidō bunka to gakkō kyōiku no senchū sengo [Wartime and postwar child culture and extracurricular education], edited by Katō Osamu, Kawakatsu Taisuke, and Asaoka Yasuō, 236-252. Kanagawa: Yūgen Kaisha Minato no Hito.

"Jidō bunka no shin-taisei" [A new order for children's culture]. 1941. Kyōiku [Education] 9(2): 12-18.

Jones, Mark. 2010. Children as Treasures: Childhood and the Middle Class in Early Twentieth Century Japan. Cambridge, MA: Harvard University Asia Center.

Kasza, Gregory J. 1995. The Conscription Society: Administered Mass Organizations. New Haven, CT: Yale University Press.

Kuchida Ichirō. 2012 (1941). "Jidō bunka to minzoku gaku” [Children's culture and folklore studies]. In Jidō bunka to gakkō kyōiku no senchū sengo [Wartime and postwar child culture and extracurricular education], edited by Katō Osamu, Kawakatsu Taisuke, and Asaoka Yasuō, 144-47. Kanagawa: Yūgen Kaisha Minato no Hito.

Kushner, Barak. 2009. "Planes, Trains and Games: Selling Japan’s War in Asia.” In Looking Modern, Taisho Japan and the Modern Era, edited by Jennifer Purtle and Hans Bjarne Thomsen, 243-64. Chicago: University of Chicago Press.

Matsuki, Keiko. 200o. "Negotiation of Memory and Agency in Japanese Oral Narrative Accounts of Wartime Experiences." Ethos 28(4): 534-50.

Montgomery, Heather. 2006. An Introduction to Childhood: Anthropological Perspectives on Children's Lives. Chichester: Wiley-Blackwell.

Mori, Kōichi. 1980. "Yanagita Kunio: An Interpretive Study." Japanese Journal of Religious Studies 7(2/3): 83-115.

Moriyama Shigeki and Nakae Kazue. 2002. Nihon kodomo shi [History of Japanese children]. Heibonsha.

Nihon Seishōnen Kyōiku Kenkyūsho. (1943) 1983. "Jidō seikatsu no jittai" [The actual state of childhood]. In Nihon jidō mondai bunken senshū [Selected documents on Japanese childhood issues], vol. 12, edited by Jidō Mondai Shi Kenkyūkai. Nihon Tosho Sentâ.

Ochanomizu gakudō sokai no kaihen, ed. 1989. Dainiji sekai taisen gakudō sokai kirokushū [Second World War school evacuation compilation]. 11 vols. Tōkyō joshi kōtō shihan gakkō fuzoku kokumin gakkō [Tokyo Women's Higher Normal School affiliated national school].

Opie, Iona, and Peter Opie. 1967. Children's Games in Street and Playground. Oxford: Oxford University Press.

Ortabasi, Melek. 2014. The Undiscovered Country: Text, Translation, and Modernity in the Work of Yanagita Kunio. Cambridge, MA: Harvard University Asia Center. 
Peak, Lois. 1993. Learning to Go to School in Japan: The Transition from Home to Preschool. Berkeley: University of California Press.

Suwa Yoshihide. 1992. Nihon no yōji kyōiku shisō to Kurahashi Sōzō [Kurahashi Sōzō and the discourse of Japanese early childhood education]. Shin Dokushosha.

Ueda Hiroaki. 2003. Sokai enikki: Gakudō sokai dosamawari [My evacuation picture diary: Child evacuation wanderings]. Bungeisha.

Yamanaka Hisashi. 1989. Zūsetsu Sensō no naka no kodomotachi: Shōwa shōkokumin bunko korekushon [Illustrated children in the war: Shōwa Little Nationals library collection]. Kawade.

Yanagita Kunio. (1941) 1990. "Kodomo fūdoki” [Regional Customs of Children]. In Yanagita Kunio zenshū [Collected works of Yanagita Kunio], vol. 23, 9-91. Chikuma Shobō.

Yoneyama, Lisa. 1999. Hiroshima Traces: Time, Space and the Dialectics of Memory. Berkeley: University of California Press.

Young, Louise. 1998. Japan's Total Empire: Manchuria and the Culture of Wartime Imperialism. Berkeley: University of California Press. 